\title{
25 YEARS OF THE NORWID FOUNDATION
}

On 15 September 1992, the District Court for the Capital City of Warsaw, $16^{\text {th }}$ Commercial and Registration Division entered our organisation in the Register of Foundations; thus, this year marks the $25^{\text {th }}$ anniversary of the establishment of this - as it was later confirmed - public benefit organisation, entitled, inter alia, to receive a $1 \%$ personal income tax deduction and other donations, and obliged to manage its funds to support the development of scientific and popularisation activities, focused on the "phenomenon of Norwid." The activities of the Norwid Foundation (NF) are set out in the statute adopted by the competent registry court.

The initiator, as well as the founder and first President of the NF is Professor Stefan Sawicki, who managed the foundation for over 20 years. 2014 marked a significant change in the Board composition, and since that time I have served as the President of the NF. I have been a member of the Foundation's Board since its inception - initially as secretary and later as vice-president. The term for office of the President and the NF Board is 3 years. The President and the Board are appointed for subsequent terms by the Founder, i.e. Professor Stefan Sawicki. The Statute allows for another way of appointing the Board, namely by entrusting this prerogative to the Audit Committee.

The current NF Board is composed of: Dr Edyta Chlebowska (Vice-President), Dr Łukasz Niewczas (Secretary), Prof. Anna Kozłowska (Board Member) and Dr hab. Włodzimierz Torun (Board Member). The members of the Board and the President perform their functions as volunteers, as do the members of the Audit Committee chaired by Andrzej Paluchowski, who died in 2017.

What are the main achievements of the foundation in its twenty-five years of existence? First of all, it must be stated that it has acted in accordance with its objectives and rights stipulated by the statute. This is really important because every year the NF is obliged to submit activity reports to the relevant state authorities re- 
sponsible for the supervision of foundations, especially those that have the status of a public benefit organisation. Each year, a board meeting is also held at which the activities of the NF are analysed and the short-term and long-term plans are discussed. The annual evaluation of the foundation's work is also performed by the Audit Committee which determines granting the approval of the performance of the Board's duties.

Secondly - this is probably the most important and developed aspect - the NF supports scientific activities and the popularisation of the life and work of Cyprian Norwid. In this area the NF really has much to boast about. From the beginning, in its statutory scope, the NF has been providing financial support for scientific works, especially for young and/or debuting scholars, by granting subsidies for research purposes and/or supporting scientific publications prepared as a result of this work. Among other things, the FN supported several publications that were published as books in the series "Studia i Monografie" [Studies and Monographs] (previously known as "Studia Norwidiana. Biblioteka"), which are published by the Learned Society of the Catholic University of Lublin (KUL) and the Centre for the Study of Cyprian Norwid's Literature and Art of the Catholic University of Lublin (KUL). ${ }^{1}$ Among others, the NF helped finance the publication of the volume with valuable studies by Elżbieta Feliksiak, Poezja i myśl. Studia o Norwidzie (Lublin 2001).

Within this aspect, perhaps above all, the FN supports the annual publishing initiative called "Studia Norwidiana," a journal focused on the phenomenon of the Foundation's patron. ${ }^{2}$ Since its beginning, that is since 1992, the NF has been involved in the preparation and scientific development of materials that constitute an important component of this national and global "body of Norwid Studies." This clear contribution takes the form of financial support for the pre-publishing process (giving opinions on each text planned to be published in the journal), and

1 The Norwid Studies Centre in Lublin was previously called the Interdepartmental Unit for the Study of Cyprian Norwid's Literature and Art, then the Institute for the Study of Cyprian Norwid's Literature and Art, and currently the Centre for the Study of Cyprian Norwid's Literature and Art, which operates at the Faculty of Humanities of the John Paul II Catholic University of Lublin.

${ }^{2}$ In the editorial of the first issue of the journal we read, among others: "Studia Norwidiana is a yearbook dedicated to the work and life of one writer. By initiating the journal in 1983, the Learned Society of the Catholic University of Lublin wants to celebrate the $100^{\text {th }}$ anniversary of Cyprian Norwid's death [...]. It is our inention that the journal contributes to the increase of the knowledge of one of the greatest, but also most difficult Polish writers [...], so that it can become a personal body of all researchers within Norwid Studies." By 2017, 35 issues of the journal had been published, with a total volume of nearly 500 publication sheets. "Studia Norwidiana" was included in the international list of scientific journals, and since 2017 it has been published on the Internet also in the English version. 
above all, financing the current annotated bibliography, which has been published since the beginning of the journal's existence, owing to specialised bibliography researchers; the bibliography department named Norwidiana was first headed by Anna Polakowska (bibliography for the years 1981-1989), her work has been continued by Aleksandra Żurawska-Włoszczyńska. Apart from that, the journal publishes extensive bibliographic blocks focused on selected areas of the literature on the subject, e.g. the bibliography of Norwid's works published in German (Wojciech Kudyba) and the bibliography of translations of Norwid's writings into English (Agata Brajerska-Mazur).

Another important activity of the NF consists of supporting the cyclical international scientific session called "Colloquia Norwidiana," which is organised every two years by the Norwid Study Centre in Lublin (KUL). The sessions are usually held in Kazimierz Dolny, but there were also wonderful scientific expeditions following the poet's artistic and intellectual fascinations: to Rome - in Quidam's footsteps; to Tuscany - in the mountains and valleys of the unique Italian beauty that so fascinated Norwid... Each session brings the fruits of wisdom and literary sensitivity of its participants in the form of publications. Our foundation participates in all these undertakings both financially and logistically.

Probably the most visible NF activity is related to honouring the most outstanding and distinguished artists and patrons of culture (including institutions) in Poland and abroad with a medal established to express gratitude to all those who serve to broaden the memory and knowledge of our poet. In the words of the poet: “Współczesnym zacnym oddać cześć, / To jakby cześć Bożej prawicy...” [Praise of living virtuous men / Is like praising God himself f $^{3}$ (Do emira Abd el Kadera w Damaszku [To Emir Abd el Kader in Damascus]).

Between 2001 and 2017, the foundation awarded this medal - a beautiful medal sculpture by Anna Beata Wątróbska-Wdowiarska - to eighteen people. We presented the first medal to the most famous "populariser" of Norwid's thought John Paul II. The ceremony of awarding the medal of gratitude took place in the Vatican in spring 2001.

Subsequent medals were awarded to scholars and cultural patrons chosen by the foundation for their contribution to the popularisation of Norwid and/or building his good image in Poland and abroad. For instance, in 2001, the medal was awarded to Cardinal Stanisław Dziwisz. In the same year, the medal was accepted by an excellent propagator of Norwid's greatness, the educator of many generations of Polish scholars - Professor Irena Sławińska. In 2002, the medal was awarded to Władysław Bartkiewicz - a faithful ally and sponsor of our foundation.

${ }^{3}$ C. NorwiD, Poezje / Poems, selection, translation and afterword by Adam Czerniawski, Kraków 1986, p. 19. 
In the same year we presented the medal to an extraordinary man and our devoted friend - Archbishop Alfons Nossol. One more medal in 2002 went to our benefactor Zenon Sroczyński. In 2003, the medal was received by Małgorzata Niemen as a tribute to her late husband, Czesław, for the unusual harmony between his musical art and the poetry of the author of Bema pamieci żalobnego-rapsodu... [A Funeral Rhapsody in Memory of General Bem...]. In 2003 we awarded Adam Czerniawski, an excellent translator of Norwid's poetry into English, living in England; he received the medal in the Józef Czechowicz Literary Museum in Lublin. In 2006 the medal went to one of the most eminent experts in the poet's work, Prof. Zofia Stefanowska. In 2008 we awarded Prof. Jadwiga Puzynina, an outstanding linguist and the creator of and head of Warsaw's Section of the Dictionary of Cyprian Norwid's Language. In 2009 the medal was awarded to the well-deserved Cyprian Norwid Cultural Centre in Kraków, and the following year the medal went to Prof. Zofia Trojanowiczowa, an outstanding researcher of Polish Romanticism and the founder of the Section of Norwid's Calendar of Life and Works in Poznań; the seminal volume Kalendarz Norwidowski was completed and published in print. In 2011 the medal was awarded to Edward Kawęcki, the long-term headmaster of Cyprian Norwid High School in Krasnystaw, the initiator and organiser of the annual nationwide knowledge competition for secondary school students centred around Norwid. In 2012 the medal went to Prof. Zdzisław Łapiński, an excellent commentator of Norwid's works, and the following year to Krzysztof Jeżewski, a translator of Norwid's poetry into French living in France and populariser of his work in Western Europe. In 2015 the Foundation honoured Prof. Stefan Sawicki, the organiser of the Lublin School of Norwid Studies with its most important distinction. In 2016 the medal was awarded to Prof. Mieczysław Inglot, a researcher and populariser of Norwid's work, and in 2017 to Prof. Rolf Fieguth, the first translator of Vade-mecum into German, a commentator of Quidam, Slavist and populariser of Slavic literature in the West, living permanently in Switzerland.

The ceremony of awarding Prof. Rolf Fieguth with the Medal of Merits for the Dissemination of Norwid's Works took place on 17 October 2017 in the music hall of the John Paul II College and was attended by both representatives of local Polish Studies and other Norwid lovers also from outside Lublin. The laudation was given by Professor Mirosława Hanusiewicz-Lavallee; the prizewinner gave a lecture entitled Chrześcijaństwo dla wszystkich - garść uwag o „Quidamie” Norwida [Christianity for all - a few remarks on Norwid's "Quidam."] Fieguth's short, synthetic speech focused on the depiction and meaning of time in the poem. It stressed the concept of con-temporaneity, i.e. a specific temporal simultaneity 
which was significant for the poet and which, in a way, resonates with his gnomic definition of time in the poem Przeszłość [The Past]:

Nie Bóg stworzył przeszłość i śmierć, i cierpienia,

Lecz ów, co prawa rwie,

$[\ldots]$

Przeszłość jest i dziś, i te dziś daléj ${ }^{4}$.

God did not create the past, nor and death nor pain,

But he who breaks the laws,

$[\ldots]$

The past is here today, and today is even further ${ }^{5}$

Hoping for future good initiatives in this Norwid's confraternity, we congratulate the Norwid Foundation on its jubilee and wish it further significant achievements within the domain of national and European culture. We also encourage potential benefactors to support us with donations, which can be given in the form of tax deduction by providing the number of the Norwid Foundation: KRS 0000129753.

${ }^{4}$ C. Norwid, Vade-mecum, compiled by J. Fert, Lublin 2004, p. 15. The version abandoned by the poet, but accepted by Z. Przesmycki, is now widely recognised: "Przeszłość, jest to $d z i s ́$, tylko cokolwiek daléj" - C. Norwid, Reszta wierszy odszukanych po dziś, a dotąd nie drukowanych, collected and published by Z. Przesmycki, Warszawa 1933, p. 33.

${ }^{5}$ C. Norwid, Poems, translated from the Polish by Danuta Borchardt in collaboration with Agata Brajerska-Mazur, New York 2012, p. 21. 